\title{
PENINGKATAN KEMAMPUAN BERPIKIR KREATIF MATEMATIS DAN SELF-CONFIDENCE SISWA SMA MELALUI \\ STRATEGI PEMBELAJARAN THINK, TALK, WRITE (TTW) DENGAN MIND MAPPING
}

\author{
Widia Siti Prayudi ${ }^{1}$, Taufik Rahman ${ }^{2}$ \\ ${ }^{1}$ Universitas Pasundan, ${ }^{2}$ Universitas Pasundan \\ widiasitiprayudi@gmail.com, taufikpmat@unpas.ac.id
}

\begin{abstract}
ABSTRAK
Kemampuan berpikir kreatif sangat penting dalam kehidupan dan segala permasalahan yang ada di dalamnya dengan cara memperoleh, mengelola, dan memanfaatkan informasi. Untuk mencapai kemampuan berpikir kreatif matematis, diperlukanlah karakter yang kuat salah satunya adalah selfconfidence. Namun pada kenyataannya kemampuan berpikir kreatif matematis dan self-confidence siswa di Indonesia masih tergolong rendah. Salah satu alternatif pembelajaran untuk meningkatkan kemampuan berpikir kreatif matematis dan self-confidence adalah dengan strategi pembelajaran Think, Talk, Write (TTW) dengan Mind Mapping. Tujuan penelitian ini adalah: 1) Untuk mengetahui apakah peningkatan kemampuan berpikir kreatif matematis siswa yang memperoleh strategi TTW dengan Mind Mapping lebih tinggi daripada siswa yang memperoleh model pembelajaran konvensional; 2) Untuk mengetahui apakah pencapaian self-confidence siswa yang memperoleh strategi TTW dengan Mind Mapping lebih baik daripada siswa yang memperoleh model pembelajaran konvensional; 3) Untuk mengetahui apakah terdapat korelasi positif antara kemampuan berpikir kreatif matematis dan self-Confidence siswa yang memperoleh strategi TTW dengan Mind Mapping. Metode yang digunakan dalam penelitian ini adalah metode kuasi eksperimen dengan desain penelitian eksperimen kelompok kontrol pretest-postest. Populasi dalam penelitian ini adalah siswa kelas X SMAN 15 Kota Bandung. Berdasarkan hasil analisis data, diperoleh kesimpulan sebagai berikut: 1) Peningkatan kemampuan berpikir kreatif matematis siswa yang memperoleh strategi TTW dengan Mind Mapping lebih tinggi daripada siswa yang memperoleh model pembelajaran konvensional; 2) Self-confidence siswa yang memperoleh strategi TTW dengan Mind Mapping lebih baik daripada dengan siswa yang memperoleh model pembelajaran konvensional; 3) Terdapat korelasi positif antara kemampuan berpikir kreatif matematis dan self-confidence siswa yang memperoleh strategi TTW dengan Mind Mapping.
\end{abstract}

Kata Kunci: Berpikir Kreatif Matematis, Self-Confidence, TTW, Mind Mapping

\begin{abstract}
Mathematical creative thinking ability is very important in life and all the problems that exist in it by obtaining, managing and utilizing information. To achieve mathematical creative thinking ability, requires the strong character one of which is self-confidence. However in reality mathematical creative thinking ability and self-confidence of students in Indonesia is still low. One alternative learning to improve mathematical creative thinking ability and self-confidence is the Think, Talk, Write (TTW) with Mind Mapping learning strategy. The purpose of this study are: 1) To find out the increase in mathematical creative thinking abilities of students who obtain TTW strategies with Mind Mapping is higher than students who obtain conventional learning models; 2) To find out the achievement of self-confidence of students who obtain TTW strategies with Mind Mapping is better than students who obtain conventional learning models; 3) To find out whether there is a positive correlation between mathematical creative thinking abilities and self-confidence of students who obtain TTW strategy with Mind Mapping. The method used in this study is a quasi-experimental method with a pretest-posttest control group experimental design. The
\end{abstract}


population of this study was tenth grade students of High School No. 15 Bandung. The sampling technique was purposive sampling, using two classes, namely the control class and the experimental class. Based on the results of data analysis, the following conclusions are obtained: 1) The increase in mathematical creative thinking abilities of students who obtain TTW strategies with Mind Mapping is higher than students who obtain conventional learning models; 2) Selfconfidence of students who obtain TTW strategies with Mind Mapping is better than with students who obtain conventional learning models; 3 ) There is a positive correlation between mathematical creative thinking ability and students' self-confidence who obtained the TTW strategy with Mind Mapping.

Keywords: Mathematical Creative Thinking, Self-Confidence, TTW, mind mapping

\section{PENDAHULUAN}

Seiring dengan pesatnya perkembangan jaman, manusia dituntut untuk mengembangkan potensi yang ada di dalam dirinya. Menurut Munirah (2015, hlm. 234) Indonesia sebagai bangsa yang dalam posisinya masih dikatakan sebagai Negara berkembang terus berupaya untuk meningkatkan mutu masyarakatnya terutama dalam bidang pendidikan karena Bangsa Indonesia menaruh harapan besar terhadap pendidikan terutama dalam pelaksanaannya di sekolah. Dalam Peraturan Pemerintah Republik Indonesia Nomor 32 tahun 2013, matematika menjadi salah satu mata pelajaran yang menjadi standar kelulusan dalam ujian nasional di seluruh jenjang pendidikan.

Pengembangan kreativitas pada matematika dinilai sangat penting, hal ini dibuktikan dengan adanya Permendikbud No. 20 Tahun 2016 tentang standar kompetensi lulusan yang mengharapkan peserta didik memiliki kemampuan berpikir dan bertindak kreatif, produktif, kritis, mandiri, kolaboratif, dan komunikatif. Maka salah satu kemampuan kognitif matematis yang dianggap penting adalah kemampuan berpikir kreatif matematis.

Pembelajaran matematika selain untuk meningkatkan kemampuan berfikir kreatif matematis atau aspek kognitif siswa, haruslah memperhatikan aspek afektif siswa, salah satu aspek afektik yang dinilai sangat penting yaitu kepercayaan diri siswa atau selfconfidence. Terdapat hubungan yang sangat kuat antara self-confidence dengan pembelajaran matematika. Yates (Hendriana, Rohaeti, \& Sumarmo, hlm. 71) menjelaskan mengenai pentingnya self-confidene bagi siswa, dimana menurutnya keberhasilan siswa dalam belajar matematika dipengaruhi oleh tingkat kepercayaan diri siswa. Dengan adanya rasa percaya diri, maka siswa akan lebih menyukai belajar matematika dan lebih termotivasi, sehingga diharapkan prestasi belajar matematika siswa nantinya akan lebih optimal. 
Namun, faktanya hasil penilaian tingkat kreativitas anak-anak Indonesia jika dibandingkan dengan negara-negara lain berada pada peringkat yang rendah. Informasi ini didasarkan pada penelitian yang dilakukan oleh Hans Jellen dari Universitas Utah, Amerika Serikat dan Klaus Urban dari Universitas Hannover, Jerman (Supriadi dalam Amiawaty, 2016, hlm. 5). Selain itu, Amiawaty (2016, hlm. 7) dalam penelitiannya menemukan bahwa kemampuan pemahaman dan berpikir kreatif matematis siswa masih rendah sehingga mengakibatkan rendahnya hasil belajar siswa. Hal ini disebabkan karena kurangnya motivasi belajar siswa, rendahnya kreatifitas siswa dalam pembelajaran, kurang semangat belajar dan kejenuhan dalam kelas. Fakta dilapangan juga menunjukan kemampuan afektif khususnya self-confidence atau kepercayaan diri siswa masih rendah terhadap pembelajaran matematika, hal ini ditunjukkan melalui penelitian yang dilakukan oleh Ramadhan (2017, hlm. 3) di SMAN 16 Bandung banyak siswa yang masih tidak percaya diri dengan kemampuannya.

Untuk mendukung sikap kognitif dan afektif siswa yang telah dijelaskan sebelumnya kita perlu strategi pembelajaran yang tepat. Oleh karena itu guru harus dapat memilih cara yang efektif yang sesuai agar siswa dapat aktif dalam proses belajar mengajar. Salah satunya adalah dengan menggunakan strategi Think, Talk, Write (TTW). Menurut Purwanto (2012, hlm. 5) Strategi Think, Talk, Write (TTW) dikembangkan dari keterlibatan siswa dari proses berpikir setelah membaca, selanjutnya kegiatan diskusi dan berbagi ide dengan teman sebayanya kemudian diungkapkan dalam tulisan atau rangkuman sesuai dengan kreativitasnya.

Penggunaan Strategi Think, Talk, Write (TTW) dinilai mampu meningkatkan kemampuan berpikir kreatif matematis siswa terutama dalam indikator berpikir luwes. Menurut Listiyani dan Kurniasih (2016, hlm. 48) pembelajaran dengan Think, Talk, Write (TTW) dapat melatih siswa untuk menuliskan hasil diskusinya ke dalam bentuk tulisan secara sistematis sehingga siswa akan lebih mudah memahami materi dan membantu siswa untuk mengkomunikasikan ide-idenya dalam bentuk tulisan. Strategi ini juga memperkenankan siswa untuk mempengaruhi dan memanipulasi ide-ide sebelum menuangkannya dalam bentuk tulisan serta membantu siswa dalam mengumpulkan dan mengembangkan ide-ide melalui percakapan terstruktur.

Berdasarkan latar belakang yang telah dipaparkan, maka tujuan penelitian ini adalah sebagai berikut: 
1. Apakah peningkatan kemampuan berpikir kreatif matematis siswa yang menggunakan strategi pembelajaran Think, Talk, Write (TTW) dengan Mind Mapping lebih tinggi daripada siswa yang memperoleh pembelajaran konvensional?

2. Apakah pencapaian Self-Confidence siswa yang menggunakan strategi pembelajaran Think, Talk, Write (TTW) dengan Mind Mapping lebih baik daripada siswa yang memperoleh pembelajaran konvensional?

3. Apakah terdapat korelasi positif antara kemampuan berpikir kreatif matematis dan self-confidence siswa yang memperoleh strategi pembelajaran Think, Talk, Write (TTW) dengan Mind Mapping di kelas eksperimen.

\section{Kemampuan Berpikir Kreatif Matematis}

Edistria (Sofia, 2018, hlm. 14) berpendapat bahwa kemampuan berpikir kreatif merupakan kemampuan untuk menciptakan sesuatu yang baru, baik berupa argument maupun karya Nyata yang relative berbeda dengan yang telah ada sebelumnya. Hal-hal baru ini tidak harus berupa asli (produk) yang benar - benar baru, meskipun hasil akhirnya mungkin akan tampak sebagai sesuatu yang baru, tetapi dapat berupa hasil penggabungan dua atau lebih konsep yang sudah ada.

Sedangkan berpikir kreatif menurut pendapat Coleman dan Hammen (Sukmadinata dalam Istianah, 2013, hlm. 46) adalah suatu kegiatan mental untuk meningkatkan kemurnian (originality) dan memperkaya wawasan (insight) dalam menghasilkan sesuatu (generating). Sehingga dapat diartikan bahwa kemampuan berpikir kreatif yaitu kemampuan untuk menghasilkan atau mengembangkan sesuatu yang baru, yaitu sesuatu yang tidak biasa yang berbeda dari ide-ide yang dihasilkan kebanyakan orang.

Indikator kemampuan berpikir kreatif diuraikan secara rinci oleh Munandar (Kurniasi, 2012, hlm. 65-66) yaitu kemampuan berpikir lancar, kemampuan berpikir luwes, kemampuan berpikir orisinal, kemampuan berpikir elaborative dan kemampuan berpikir evaluatif.

\section{Self-Confidence}

Menurut Suhendri (Suhendri, 2012, hlm. 398-399) bahwa "rasa percaya diri adalah suatu sikap mental atau psikologis positif dari seorang individu yang memposisikan atau mengkondisikan dirinya dapat mengevaluasi tentang diri sendiri dan lingkungannya sehingga merasa nyaman untuk melakukan kegiatan dalam upaya mencapai tujuan yang direncanakan." Berdasarkan hal tersebut, rasa percaya diri merupakan suatu sikap positif 
yang dapat menimbulkan seseorang dapat mengenali potensi dirinya dan lingkungan sekitarnya dalam melakukan suatu kegiatan.

Self Confidence atau Kepercayaan diri menurut Bandura (Hendriana, Rohaeti, \& Sumarmo, 2017, hlm.198) merupakan rasa percaya terhadap kemampuan diri dalam menyatukan dan menggerakan (memobilisasi) motivasi dan semua sumber daya yang dibutuhkan, dan memunculkannya dalam tindakan yang sesuai dengan apa yang harus diselesaikan, sesuai tuntutan tugas.

Menurut Lautser (Fitriani dalam Hendriana, Rohaeti, \& Sumarmo, 2017, hlm. 198) aspek-aspek self confidence adalah Keyakinan kemampuan diri; Optimis; Objektif; Bertanggung Jawab; dan Rasional realistis.

\section{Strategi Pembelajaran Think, Talk, Write (TTW) Dengan Mind Mapping}

Penggunaan strategi Think, Talk, Write (TTW) memungkinkan terjadinya aktivitas berpikir, berkomunikasi dan mengkontruksi ide berdasarkan pemahaman dan pengetahuan yang diperolehnya. Kemudian penggunaan teknik mind mapping dalam strategi Think, Talk, Write (TTW) memungkinkan siswa untuk meningkatkan kreativitasnya. Teknik mind mapping dimulai dengan suatu tema atau gagasan yang memiliki banyak solusi pemikiran yang akan menjadi umpan untuk siswa berfikir dan menghasilkan banyak gagasan lainnya. Dengan menggunakan mind mapping, siswa dapat menyusun gagasan dan ide dalam fikirannya yang beracuan kepada tema tunggal tersebut. Selain itu juga penggunaan mind mapping dapat membuat sebuah materi yang dinilai rumit dapat dibuat menjadi gagasan singkat, menarik dan mudah dipahami siswa.

Menurut Firdaus (2017, hlm. 3) dalam pembuatan mind mapping, siswa dilatih memiliki kemampuan orisinil yang membangun sesuatu dari ide-idenya. Siswa menuangkan gagasannya dalam bentuk mind mapping yang unik. Selain itu dengan menyajikan di depan kelas, siswa akan memahami mind map yang dia buat sendiri dan berlatih untuk mengungkapkan gagasannya di depan kelas.

Perlu langkah-langkah dalam menggunakan mind mapping ini untuk mendukung kemampuan kognitif dan afektif siswa. Oleh karena itu langkah-langkahnya yaitu dengan mengkolaborasikan model mind mapping dengan strategi think, talk, write (TTW). Kolaborasi antara strategi Think-Talk-Write (TTW) dengan mind mapping meliputi sebagai berikut:

1. Tahap Think 
Dalam tahap ini, siswa secara individu siswa membaca teks dan membuat catatan dari hasil bacaan secara individual untuk dibawa ke forum diskusi. Siswa memirkinkan kemungkinan pertanyaan yang akan muncul, poin-poin penting dalam materi, tema utama dan tema cabangnya, menandai konsep yang penting atau hal yang tidak ia pahami.

2. Tahap Talk

Dalam tahap ini, siswa berinteraksi dan berkolaborasi dengan teman satu grup untuk membahas isi catatan, menyatukan pendapat tentang poin-poin penting apa saja dalam tema utama atau konsep yang diberikan, serta memberikan solusi dalam permasalahan yang muncul.

\section{Tahap Write}

Dalam tahap ini, Siswa mengkontruksi sendiri pengetahuan bentuk Mind Map (write). Poin-poin penting yang telah didiskusikan menjadi poin utama dalam peta pikiran, dan poin-poin turunan menjadi cabang dari poin-poin utama, Siswa dibebaskan untuk berkreatifitas dalam pembuatan Peta Pikirannya.

\section{Refleksi}

Diakhir tahap, guru memberikan latihan soal. Siswa diharapkan mengerjakan latihan soal dengan menggunakan kembali langkah-langkah dari strategi Think, Talk, Write (TTW) dengan mengingat kembali mind map atau peta pikiran yang sebelumnya telah mereka buat. Setiap siswa harus benar-benar memahami jawaban yang disetujui. Untuk membuktikannya guru harus mengulang kembali jawabannya dan mungkin menulis atau menggambarkannya di papan tulis (tapi tanpa tambahan komentar). Jika waktu habis sebelum kesepakatan diraih, guru dapat memberikan ringkasan sampai bagian yang telah diraih kemudian guru bisa menyimpulkan hasil diskusi serta menyakinkan siswa bahwa kesimpulan ini dapat diterima.

\section{METODE PENELITIAN}

Penelitian ini menggunakan metode penelitian kuasi eksperimen dengan desain penelitian kelompok kontrol pretes-postes. Dimana diambil dua kelas yaitu kelas eksperimen dan kelas kontrol untuk melihat strategi pembelajaran Think, Talk, Write (TTW) dengan Mind Mapping sebagai variabel bebas dalam meningkatkan kemampuan berpikir kreatif matematis dan keberpengaruhan terhadap self-onfidence sebagai variabel terikat. Populasi dalam penelitian ini adalah SMA Negeri 15 Bandung dengan sampelnya yaitu kelas X Mipa 5 sebagai kelas TTW dan X Mipa 6 sebagai kelas konvensional. Pada tahap awal, kelas eksperimen maupun kelas kontrol diberikan pretest berupa pemberian 
instrument tes kemampuan berpikir kreatif matematis dengan tujuan untuk mengukur kemampuan awal berpikir kreatif matematis. Pelaksanaan pembelajaran pada kedua kelas dilakukan dengan model pembelajaran yang berbeda, dimana kelas eksperimen akan diberikan pembelajaran dengan strategi pembelajaran Think, Talk, Write (TTW) dengan Mind Mapping sedangkan kelas kontrol akan diberikan pembelajaran konvensional. Model-model tersebut ini diberikan dan diterapkan selama kegiatan pembelajaran berlangsung. Pada tahap akhir, setiap kelas diberikan postes dan angket self-confidence yang sama hal ini dilakukan untuk mengetahui perkembangan dan peningkatan kemampuan berpikir kreatif dan mengetahui penilaian self-confidence matematis siswa setelah melaksanakan pembelajaran. Data yang terkumpul kemudian diolah menggunakan software IBM SPSS 23.0 for Windows.

\section{HASIL DAN PEMBAHASAN}

Setelah mendapatkan data pretes dan postes kemampuan berpikir kreatif matematis, selanjutnya dilakukan analisis pada data $\mathrm{N}$-gain kemampuan berpikir kreatif matematis menggunakan program SPSS 23 for windows. Berikut ini disajikan statistik deskriptif dan statistik inferensial dari kemampuan berpikir kreatif matematis.

Tabel 1. Statistik Deskriptif Kemampuan Berpikir Kreatif Matematis Siswa

\begin{tabular}{ccccccccccc}
\hline & \multicolumn{4}{c}{ Kelas Eksperimen } & \multicolumn{6}{c}{ Kelas Kontrol } \\
\cline { 2 - 11 } & \multirow{2}{*}{$\mathrm{N}$} & $\begin{array}{c}\text { Nilai } \\
\text { Min }\end{array}$ & $\begin{array}{c}\text { Nilai } \\
\text { Maks }\end{array}$ & \multirow{2}{*}{ Mean } & S & N & $\begin{array}{c}\text { Nilai } \\
\text { Min }\end{array}$ & $\begin{array}{c}\text { Nilai } \\
\text { Maks }\end{array}$ & \multirow{2}{*}{ Mean } & S \\
\hline Pretes & 32 & 3 & 45 & 22,53 & 10,04 & 32 & 3 & 41 & 21,91 & 10,23 \\
Postes & 32 & 35 & 100 & 71,09 & 17,72 & 32 & 18 & 90 & 63,16 & 16,56 \\
N-Gain & 32 & 0,13 & 1 & 0,62 & 0,06 & 32 & 0,12 & 0,88 & 0,52 & 0,04 \\
\hline
\end{tabular}

Tabel 2. Statistik Inferensial Data N-Gain Kemampuan Berpikir Kreatif Matematis Siswa $(\alpha=0,05)$

\begin{tabular}{cccc}
\hline \multirow{2}{*}{ Kelas } & Uji Normalitas & Uji Homogenitas & Uji-t \\
\cline { 2 - 4 } & $\begin{array}{c}\text { Shapiro-Wilk } \\
\text { (Sig.) }\end{array}$ & Levene stat. (Sig.) & $\begin{array}{c}\text { Independent Sample T-Test } \\
\text { Sig. (2-tailed) }\end{array}$ \\
\hline $\begin{array}{c}\text { Eksperimen } \\
\text { Kontrol }\end{array}$ & 0,150 & 0,132 & 0,093 \\
\hline
\end{tabular}

Selain itu dilakukan analisis data hasil angket self-confidence yang diberikan pada siswa setelah pembelajaran dilakukan. Berikut ini disajikan statistik deskriptif dan statistik inferensial dari self-confidence.

Tabel 3. Statistik Deskriptif Self-Confidence

\begin{tabular}{ccccccccccc}
\hline & \multicolumn{4}{c}{ Kelas Eksperimen } & \multicolumn{5}{c}{ Kelas Kontrol } \\
\cline { 2 - 11 } & $\mathrm{N}$ & $\begin{array}{c}\text { Nilai } \\
\text { Min }\end{array}$ & $\begin{array}{c}\text { Nilai } \\
\text { Maks }\end{array}$ & Mean & S & N & $\begin{array}{c}\text { Nilai } \\
\text { Min }\end{array}$ & $\begin{array}{c}\text { Nilai } \\
\text { Maks }\end{array}$ & Mean & $\mathrm{S}$ \\
\hline Angket & 32 & 71,25 & 119,41 & 87,27 & 11,09 & 32 & 62,69 & 99,88 & 83,43 & 9,35 \\
\hline
\end{tabular}


Tabel 4. Statistik Inferensial Self-Confidence $(\alpha=0,05)$

\begin{tabular}{cccc}
\hline \multirow{2}{*}{ Kelas } & Uji Normalitas & Uji Homogenitas & Uji-t \\
\cline { 2 - 4 } & $\begin{array}{c}\text { Shapiro-Wilk } \\
\text { (Sig.) }\end{array}$ & Levene stat. (Sig.) & $\begin{array}{c}\text { Independent Sample T-Test } \\
\text { Sig. (2-tailed) }\end{array}$ \\
\hline $\begin{array}{c}\text { Eksperimen } \\
\text { Kontrol }\end{array}$ & 0,211 & 0,443 & 0,069 \\
\hline
\end{tabular}

Berdasarkan Tabel 1 di atas terlihat bahwa nilai minimum, nilai maksimum dan rata-rata dari $\mathrm{N}$-gain kemampuan berpikir kreatif matematis kelas eksperimen lebih tinggi daripada kelas kontrol. Siswa kelas eksperimen mendapat rata-rata sebesar 0,62 lebih besar dibandingkan kelas kontrol memiliki peningkatan kemampuan berpikir kreatif matematis sebesar 0,52 yang artinya secara deskriptif peningkatan kemampuan berpikir kreatif kelas TTW lebih baik dari kelas konvensional. Hal ini disebabkan oleh perilaku yang diberikan pada kedua kelas saat pembelajaran berlangsung, dimana kelas eksperimen memperoleh strategi pembelajaran Think, Talk, Write (TTW) dengan Mind Mapping sedangkan kelas kontrol memperoleh pembelajaran konvensional. Selain itu pada Tabel 2 terlihat data Ngain kedua kelas menujukan berdistribusi normal dan homogen, kemudian dilakukan uji-t diperoleh signifikansi 0,093 hasil ini menyatakan bahwa peningkatan kemampuan berpikir kreatif matematis siswa yang memperoleh strategi pembelajaran Think, Talk, Write (TTW) dengan Mind Mapping lebih tiggi daripada siswa yang memperoleh model pembelajaran konvensional.

Pada Tabel 3 terlihat bahwa nilai minimum, nilai maksimum dan rata-rata dari data hasil angket self-efficacy kelas eksperimen lebih tinggi daripada kelas kontrol, dimana pada kelas eksperimen yaitu 87,27 sedangkan pada kelas kontrol yaitu 83,43. Tabel 4 menunjukan bahwa kedua kelas berdistribusi normal dan homogen. Kemudian dilanjutkan dengan uji-t diperoleh nilai signifikasinya 0,069 yang artinya bahwa self-confidence matematis siswa yang memperoleh strategi pembelajaran Think, Talk, Write (TTW) dengan Mind Mapping lebih baik dari pada siswa yang memperoleh pembelajaran konvensional.

Untuk mengetahui apakah terdapat korelasi positif antara kemampuan berpikir kreatif matematis dan self-confidence siswa yang memperoleh strategi pembelajaran Think, Talk, Write (TTW) dengan Mind Mapping dengan menggunakan perhitungan korelasi Pearson Product Moment diperoleh hasil sebesar 0,94. Hal ini menunjukan bahwa terdapat korelasi positif antara kemampuan berpikir kreatif dan self-confidence siswa yang memperoleh strategi pembelajaran Think, Talk, Write (TTW) dengan Mind Mapping. 
Uraian dari hasil analisis di atas menunjukan bahwa siswa yang memperoleh strategi pembelajaran Think, Talk, Write (TTW) dengan Mind Mapping mampu menunjukan pencapaian dan peningkatan kemampuan berpikir kreatif matematis yang lebih tinggi daripada siswa yang memperoleh pembelajaran konvensional. Terlihat dari perolehan rata-rata postes kelas eksperimen yaitu 71,09 dan kelas kontrol 63,16, angka tersebut menunjukan bahwa rata-rata postes kelas eksperimen lebih tinggi daripada kelas kontrol. Selain itu untuk rata-rata N-gain pada kelas eksperimen yaitu 0,13 dan kelas kontrol 0,12, maka rata-rata $\mathrm{N}$-gain kelas eksperimen lebih tinggi daripada kelas kontrol. Hasil analisis pada self-confidence juga menunjukan bahwa siswa yang memperoleh strategi pembelajaran Think, Talk, Write (TTW) dengan Mind Mapping memiliki selfconfidence matematis yang lebih baik daripada siswa yang memperoleh pembelajaran konvensional. Terlihat dari perolehan rata-rata angket kelas eksperimen yaitu 87,27 dan kelas kontrol 83,43, angka tersebut menunjukan bahwa rata-rata hasil angket selfconfidence kelas eksperimen lebih baik daripada kelas kontrol.

Dari hasil penelitian yang telah dilakukan untuk menentukan peningkatan kemampuan berpikir kreatif matematis peserta didik menunjukkan bahwa pembelajaran dengan menggunakan strategi pembelajaran Think, Talk, Write (TTW) dengan mind mapping dapat mendukung peserta didik dalam mengembangkan kemampuan berpikir kreatif matematis. Menurut Purwanto (2012, hlm. 5) Strategi Think, Talk, Write (TTW) ini dikembangkan dari keterlibatan siswa dari proses berpikir setelah membaca dan menarik poin-poin penting dari apa yang ia baca dan fikirkan (Tahap Think), yang selanjutnya berbagi ide (sharing) dengan diskusi bersama teman lain atau dalam kelompok kemudian (Tahap Talk) dan dituangkan dalam tulisan atau rangkuman sesuai dengan kreativitasnya (Tahap Write), dengan tahap write disini yaitu menggunakan media mind mapping. Pada proses pembelajaran terjadi aktivitas berpikir, berkomunikasi dan mengkontruksi ide berdasarkan pemahaman dan pengetahuan yang diperolehnya

Tiga tahap dari strategi pembelajaran Think, Talk, Write (TTW) dengan mind mapping mendukung untuk mengembangkan indikator kemampuan berpikir kreatif matematis peserta didik. Setiap tahap menuntut peserta didik untuk berfikir kreatif dan mandiri dalam menganalisis LKPD, menyajikan masalah dan menyelesaikan masalah baik secara lisan maupun tulisan, menyajikan pemikirian mereka dalam bentuk tulisan atau gambar secara kreatif dan mempresentasikan hasil pengerjaan setiap kelompok, menarik kesimpulan. 
Selain itu Sesuai dengan pengertian Self Confidence menurut Bandura (Hendriana, Rohaeti, \& Sumarmo, 2017, hlm.198) yaitu merupakan rasa percaya terhadap kemampuan diri dalam menyatukan dan menggerakan (memobilisasi) motivasi dan semua sumber daya yang dibutuhkan, dan memunculkannya dalam tindakan yang sesuai dengan apa yang harus diselesaikan, sesuai tuntutan tugas. Siswa yang memperoleh strategi pembelajaran Think, Talk, Write (TTW) dengan mind mapping terlihat lebih aktif dalam kelompok. Mereka tidak hanya terfokus dalam satu sumber saja yaitu guru tetapi mereka juga mencari pengetahuan dari sumber lain yang relevan dengan materi yang sedang dibahas. Mereka juga lebih berinisiatif dalam melaksanakan tuntutan tugas yang diberikan oleh guru. Mereka juga dapat memakai beberapa cara ketika mengerjakan soal. Selaras dengan pendapat Buzan (Asri dkk, 2015) bahwa teknik mind mapping akan membuat pembaca menjadi senang, memahami bacaan, dan melatih siswa menggunakan pikiran secara efektif. Sedangkan kelas yang memperoleh model pembelajaran konvensional lebih terpaku kepada penjelasan guru. Mereka merasa kebingungan ketika diberikan soal yang berbeda dari contoh oleh guru. Membutuhkan waktu yang cukup lama juga untuk meminta siswa di kelas kontrol maju ke depan menjawab soal yang diberikan guru.

Melihat hasil dari pembelajaran dengan strategi pembelajaran Think, Talk, Write (TTW) dengan mind mapping yang memberikan korelasi positif terhadap kemampuan berpikir kreatif matematis dan self-confidence siswa, hal tersebut menunjukan bahwa dengan pembelajaran strategi pembelajaran Think, Talk, Write (TTW) dengan mind mapping dapat menjadi alternatif model pembelajaran yang diterapkan disekolah untuk meningkatkan kemampuan berpikir siswa.

\section{KESIMPULAN}

Berdasarkan hasil analisis data dan pembahasan sebelumnya. diperoleh kesimpulan sebagai berikut:

1. Peningkatan kemampuan berpikir kreatif matematis peserta didik yang memperoleh strategi pembelajaran Think, Talk, Write (TTW) dengan Mind Mapping lebih tinggi daripada peserta didik yang memperoleh model pembelajaran konvensional.

2. Self-Confidence peserta didik yang memperoleh strategi pembelajaran Think, Talk, Write (TTW) dengan Mind Mapping lebih baik daripada peserta didik yang memperoleh model pembelajaran konvensional. 
3. Terdapat korelasi antara kemampuan berpikir kreatif matematis dan self-confidence peserta didik yang memperoleh strategi pembelajaran Think, Talk, Write (TTW) dengan Mind Mapping.

\section{REFERENSI}

Amiawaty, A. (2016). Pendekatan kontekstual dalam pembelajaran matematika untuk meningkatkan kemampuan pemahaman dan berpikir kreatif serta kemandirian belajar matematis siswa SMP. Tesis Unpas Bandung: Tidak diterbitkan.

Asri, I.G.A.A.S., Yuliasih, N. L., Wiyasa, I. (2015). Penerapan Mind Mapping dalam Pendekatan Saintifik untuk Meningkatkan Hasil Belajar PKN dan Sikap Spiritual pada Tema Cta-citaku Siswa Kelas IVA SD Negeri 24 Pemecutan. E-Journal Universitas Pendidikan Ganesha. Jurusan PGSD. Volume 3 No. 1 Firdaus, M. (2017). Penerapan model pembelajaran mind mapping terhadap peningkatan kemampuan berpikir kreatif matematik dan self-regulated learning siswa SMP. Skripsi Unpas Bandung: Tidak diterbitkan.

Hendriana, H., Rohaeti, E.E., \& Sumarmo, U. (2017). Hard skills dam soft skills matematik siswa. Bandung: PT Refika Aditama.

Istianah, E. 2013. Infinity Jurnal Ilmiah STKIP Siliwangi Bandung, 34(2). 43-54. [Online]. Tersedia: http://ejournal.stkipsiliwangi.ac.id/index.php/infinity/article/view/23 (diakses pada tanggal 12 Desember 2018)

Kurniasi, E. R. 2012. Pengaruh pembelajaran matematika dengan mind map terhadap kemampuan berpikir kreatif pada siswa SMA. Symmetry. 1(1). 61-71.

Listiyani, E. \& Kurniasih, N. (2016). Peningkatan kemampuan berpikir kreatif dan representasi matematis dengan model pembelajaran TTW berbantuan pocket book. Ekuivalen. 24(1). 46-51. [Online] Tersedia: http://ejournal. umpwr.ac.id/index.php/ekuivalen/article/view/3190/3002 (Diakses pada tanggal 15 Mei 2019)

Munirah. (2015) Sistem pendidikan di Indonesia: antara keinginan dan realita. Auladuna. 2(2). 233-245. [Online] Tersedia: http://journal.uin-alauddin.ac.id/index.php /auladuna/article/view/879/849 (Diakses pada tanggal 15 Mei 2019)

Permendikbud. (2016). Standar Kompetensi Lulusan Pendidikan Dasar dan Menengah nomor 20 Tahun 2016.

Peraturan Pemerintah Republik Indonesia. (2013). Standar Nasional Pendidikan nomor 32 Tahun 2013.

Purwanto, Budi. (2012). Eksperimentasi model pembelajaran kooperatif tipe think-talkwrite (TTW) dan tipe think-pair-share (TPS) pada materi statistika ditinjau dari kemandirian belajar siswa SMA di kabupaten Madiun. Tesis Universitas Sebelas Maret Surakarta: Tidak diterbitkan

Ramadhan, Rizky. (2017). Pengaruh model pembelajaran meaningful instructional design (MID) terhadap peningkatan kemampuan penalaran matematis dan self-confidence siswa SMA. Skripsi Unpas Bandung: Tidak diterbitkan.

Suhendri, H. 2012. Pengaruh kecerdasan matematis-logis, rasa percaya diri, dan kemandirian belajar terhadap hasil belajar matematika. Prosiding Seminar Nasional Matematika dan Pendidikan Matematika UNY 10 November 2012. [Online]. Tersedia: https://eprints.uny.ac.id/8082/ (diakses pada tanggal 2 April 2019) 